\author{
Review Article, Britannia 49, 2018
}

\title{
Putting a Face to Longinus: Rethinking the Imperial Auxilia for the Twenty-First Century
}

\author{
By SIMON JAMES
}

Blood of the Provinces: The Roman Auxilia and the Making of Provincial Society from Augustus to the Severans. By I. Haynes. OUP, Oxford 2013 (paperback edition 2016). Pp. xviii + 430, 49 figures (line drawings and half-tone photographs) and 2 tables. Price: $£ 110(\mathrm{Hb})$ or $£ 30(\mathrm{~Pb})$. ISBN, HB 978 019965534 2, PB 9780198795445.

Blood of the Provinces was first published in 2013, but somewhat unaccountably did not then receive a review in Britannia. This was unfortunate, as it is a very important book. Appearance of a paperback edition in 2016, although differing from the hardback only in correction of typographical errors, provides a welcome second opportunity to consider it.

In this substantial volume Haynes traces the evolution of the regular imperial auxilia from their Augustan origins to the third century. Its 22 chapters are divided into seven parts: the auxilia and the structures of imperial power; the 'human resource', addressing recruitment and its consequences; daily life in the auxilia; religion, ritual and cult; equipment, tactics and identity; 'communication and cultural transformation', dealing with the spoken and written word; and finally auxiliary veterans and the making of provincial society.

This is a fresh and original treatment of a major aspect of the Roman military, published a century after the pioneering work of Cheesman (The Auxilia of the Roman Imperial Army), which appeared in 1914 a year before his tragically early death at Gallipoli. Cheesman's book laid the initial groundwork for study of the auxilia, anatomising their organisation and military raison d'être, and considering their recruitment. It became the starting point for later scholars exploring particular aspects of the subject, some of which only became scholarly priorities in the long aftermath of another World War. To Cheesman's officer-class perspective of organisation and 
operations have been added those of social history, not least regarding the experience of ordinary Roman soldiers. For example, MacMullan's seminal 1984 paper 'The legion as a society' (Historia: Zeitschrift für Alte Geschichte 33, 440-56), which also considered auxiliary units, opened up new avenues of research by stressing the social dynamics interacting with institutional structures within the imperial military.

H.'s book, the first comprehensive monograph on the subject since Cheesman's, does not seek merely to update the picture given by the earlier volume, on the basis of the vast mass of new data and publications now available to us, especially arising from the efforts of archaeologists over the last century. Rather, in a number of key respects Blood of the Provinces profoundly revises our picture of the non-legionary half of the armies of the Principate. It does this by successfully challenging a number of widely held beliefs about auxiliaries. The book also achieves something of much broader significance, an objective embedded in the title: far more comprehensively than previous treatments, it places auxiliary soldiers and their officers in the wider context of contemporary Roman society - or perhaps better, of the empire's multiple societies, metropolitan and provincial. It underlines the reality that the Roman auxilia (and indeed Rome's armies and soldiers as an entirety) were a major and integral part of the social and cultural history of the Roman world, which cannot be properly understood without taking them fully into account. This enriches military studies and also makes an invaluable contribution to addressing a wider problem: the longstanding 'ghettoisation' of military studies, especially in Anglophone scholarship on Rome.

For decades, work on the Roman military, archaeological, epigraphic and historical, has tended to be a preserve largely separate from the mainstream of Roman studies, which have concentrated on civil topics, with archaeology in particular since the 1980s undergoing a revolution in its approach to theory. There has, of course, been important work spanning this divide, for example by Andrew Gardner (An Archaeology of Identity: soldiers and society in late Roman Britain (2007)), and in recent years multiple other welcome signs of its weakening. Nonetheless a significant gulf of interest and understanding has remained between now-dominating, strongly postcolonial Roman scholarship, and imperial military and frontier studies which others still often regard as metaphorically if not literally peripheral, and archaic in approach if not ideologically suspect.

In Blood of the Provinces, H. exhibits a judicious balance, exhibiting equally sure grasps 
both of traditional military scholarship, with its emphasis on the rich detail of the data - he demonstrates command of a vast range of material from right across the empire, archaeological, epigraphic and historical - and of the theoretical underpinnings of his approach. For example, a prominent theme running through the book is emphasis on the body, both as a physical entity and as a metaphor, involving 'incorporation' of individuals into Roman service as men who 'embodied the authority of Rome to many of the provincials they encountered' (p. 23). H.'s keen eye also provides significant new perspectives on traditional topics, such as the relatively exotic martial embodiment of many auxiliaries through their particular dress and fighting equipment. The auxilia - especially cavalry - fascinated (and still fascinate) through the visual spectacle of equipment largely derived from the martial material culture of subject peoples from Spain to Syria. However, H. also challenges the widely held impression of sustained and substantial ethnically-based material diversity, noting that 'Whatever the literary elite might have fantasised, by the second century. the arms and armour of equites and cohortales showed a high degree of similarity' (p. 287).

More profoundly, he radically alters our picture of the nature and significance of 'ethnic' recruitment. In particular, he successfully challenges the long-held belief going back to Cheesman that 'ethnic regiments', notably eastern archer formations, continued to recruit from their original homelands long after they were raised and posted to other parts of the empire. Underpinned by modern theoretical understandings of ethnicity, Haynes offers a historiographical critique of British imperial thinking of Cheesman's time about 'martial races' and of the retrojection of this notion onto the Roman era, and argues this generated factoids such as the notion that good archers could only be made from men accustomed to the bow since childhood in places like Syria. Through detailed review of the primary evidence, notably relating to nominally Syrian units from Intercisa, H. creates a convincing case that replacement manpower for auxiliary units generally came from the nearest convenient source at the time.

Recruitment of hundreds of thousands of peregrini into the auxilia, largely through conscription, had massive effects on the development of Roman provincial societies, perhaps most famously on the Batavi. It is in considering the wider impact of the creation and maintenance of the auxilia on the provinces that H.'s book is likely to have its broadest and most important impact on the study of the Roman world. In some respects, his careful analysis serves as a valuable corrective to established assumptions, notably in questioning the plausible scale of impact of auxiliary 
veterans in shaping the emergence of Roman-style provincial communities. On the other hand, he explores the implications of wider recent work bringing auxiliaries' families and dependants into the picture, which transforms our understanding of the nature of Roman military as a social phenomenon. He conceptualises it as comprising communities in two senses, 'occupational communities' of the soldiers themselves and broader 'military communities' of milites with all their dependants, social entities scattered across the empire and forming influential components of wider society, not only throughout the frontier provinces, but also in Rome itself.

To conclude, the book's cover offers a fitting metaphor for its contents. It features the tombstone of the Thracian cavalryman Longinus, found in 1928 at Colchester, damaged, literally faceless. In recent times he has reacquired his face (found in 1996), transforming our literal picture of him, as in this book $\mathrm{H}$. does so much to transform our metaphorical picture of hundreds of thousands of Longinus's commilitones. H.'s book is the first fully rounded attempt to evoke auxiliaries as people, family men and social actors, not just within the context of Rome's armies but also in the creation of provincial societies. A century on, it is a worthy twenty-first century volume to place alongside Cheesman's classic. 